\title{
PERSEPSI MAHASISWA PENDIDIKAN MATEMATIKA TERHADAP PELAKSANAAN PERKULIAHAN ONLINE DI MASA PANDEMI COVID-19
}

\author{
Hesty Marwani Siregar ${ }^{1}$, Syarifah Nur Siregar ${ }^{2}$, Titi Solfitri ${ }^{3}$ \\ Pendidikan Matematika, Universitas Riau ${ }^{1,2,3}$ \\ Email: hesty.marwani@lecturer.unri.ac.id
}

\begin{abstract}
Abstrak
Adanya penyebaran virus Corona mengakibatkan kegiatan perkuliahan yang biasanya dilakukan secara tatap muka harus dilakukan secara online. Oleh karena itu, persepsi mahasiswa terhadap perkuliahan online yang telah berlangsung perlu diketahui. Tujuan dari penelitian ini untuk menjelaskan persepsi mahasiswa Pendidikan Matematika Universitas Riau terhadap pelaksanaan perkuliahan online di masa pandemi Covid-19. Penelitian ini menggunakan pendekatan kuantitatif deskriptif. Data yang diperoleh dari mahasiswa adalah skor persepsi mahasiswa Pendidikan Matematika Universitas Riau terhadap pelaksanaan perkuliahan online di masa pandemi Covid-19 Hasil yang diperoleh menunjukkan bahwa secara umum pelaksanaan perkuliahan online pada Program Studi Pendidikan Matematika Universitas Riau telah memperoleh respon positif, yaitu berada pada kategori sedang, tinggi, dan sangat tinggi. Dilihat dari indikator yang digunakan pada setiap aspek yang diteliti, maka: 1) pada aspek persepsi mahasiswa tentang dirinya selama mengikuti perkuliahan online, 3 indikator berada pada kategori cukup dan 1 indikator berada pada indikator kurang; 2) pada aspek persepsi mengenai proses perkuliahan online yang ideal, 1 indikator berada pada kategori sangat baik, 1 indikator berada pada kategori baik, dan 2 indikator berada pada kategori cukup; 3) pada aspek persepsi terkait perkuliahan online yang terjadi, 2 indikator berada pada kategori cukup dan 2 indikator berada pada kategori sangat kurang.
\end{abstract}

Kata Kunci : persepsi, perkuliahan online, pandemi covid-19

\begin{abstract}
The spread of the Coronavirus has resulted in lecture activities that are usually carried out face-toface to be carried out online. Therefore, students' perceptions of online lectures need to be known. The purpose of this study is to explain the perceptions of Mathematics Education student of Universitas Riau towards the implementation of online lectures during the Covid-19 pandemic. This study uses a descriptive quantitative approach. The data obtained from students was the perception score of students. The results obtained indicated that the implementation of online lectures had received a positive response, which was in the medium, high, and very high category. Judging from the indicators used in each aspect studied, then: 1) in the aspect of students' perceptions of themselves during online lectures, 3 indicators were in the sufficient category and 1 indicator was in the less indicator; 2) on the aspect of perception regarding the ideal online learning process, 1 indicator was in the very good category, 1 indicator was in a good category, and 2 indicators were in the sufficient category; 3) on the aspect of perception related to online learning that occurs, 2 indicators were in the sufficient category and 2 indicators were in the very poor category.
\end{abstract}

Key Words : perception, online lectures, the covid-19 pandemic

\section{PENDAHULUAN}

Di akhir tahun 2019, muncul wabah penyakit baru dengan gejala demam, batuk kering, dan kelelahan yang terjadi di Wuhan. Patogen wabah ini diidentifikasi sebagai virus beta-corona baru, bernama 2019 novel coronavirus (2019-nCoV) yang gejalanya memiliki kemiripan dengan sindrom pernapasan akut yang parah yaitu SARS (disebabkan oleh beta-coronavirus lain) yang terjadi pada tahun 2003 [1].

Kemunculan virus corona dan upaya yang dilakukan dalam mengurangi penularannya memberikan dampak di berbagai sektor kehidupan. Salah satu akibat munculnya 
wabah virus corona ini antara lain munculnya sindrom panic karena ketakutan terhadap virus corona [2]. Di bidang perekonomian, dampak yang dirasakan seperti daya beli masyarakat menurun, kehilangan pekerjaan, penurunan pendapatan, kinerja perusahaan di sektor transportasi dan pariwisata menurun, dan berkurangnya investasi asing di Indonesia yang mempengaruhi keberlangsungan proyek strategis Indonesia [3]. Bidang pendidikan juga turut merasakan dampak dari pandemi ini. Pemberlakuan kebijakan lockdown, PSBB (Pembatasan Sosial Berskala Besar), ataupun physical distancing mengakibatkan kegiatan pembelajaran secara tatap muka, baik di tingkat sekolah dasar, menengah, maupun di tingkat tinggi tidak dapat dilakukan. Untuk itu, kegiatan pembelajaran secara online mulai diberlakukan.

Kuliah online adalah kegiatan pembelajaran di perguruan tinggi yang dilakukan dengan menggunakan internet. Perkuliahan online merupakan suatu bentuk perkuliahan yang tidak dilakukan dengan tatap muka langsung, baik dosen maupun mahasiswa tidak harus berada di kampus saat perkuliahan berlangsung. Dosen dan mahasiswa bisa melaksanakan kegiatan pembelajaran menggunakan platform yang telah disepakati bersama, sesuai dengan kebutuhan pembelajaran.

Faktanya, secara umum, pelaksanaan kuliah online mendapat tanggapan yang beragam dari berbagai kalangan masyarakat. Dari kalangan mahasiswa, ada yang merasa bahwa kuliah online memberikan kemudahan dari segi waktu. Waktu untuk melaksanakan kuliah online fleksibel, dapat dilaksanakan pagi, siang, sore, ataupun malam hari. Selain itu, kuliah online mudah diakses dimana saja jika sinyal memadai, mampu menghemat waktu, dan menarik sehingga minat mengikuti perkuliahan tinggi [4]. Ada pula mahasiswa yang merasa bahwa kuliah online membutuhkan biaya kuota internet yang besar, sehingga untuk menghemat biaya kuota internet, mahasiswa tersebut terpaksa tetap berangkat ke kampus untuk dapat menggunakan wifi gratis. Selain itu, mahasiswa juga merasa bahwa tugas yang diberikan beberapa dosen lebih banyak daripada ketika kuliah tatap muka [5].

Selain tanggapan mahasiswa mengenai pelaksanaan kuliah online, penilaian dosen mengenai pembelajaran menggunakan kuliah online pun beragam. Dari segi perkuliahan yang telah berlangsung, sebagian dosen merasa mahasiswa lebih aktif bertanya dan berpartisipasi pada saat perkuliahan online dibandingkan pada saat tatap muka [6]. Sementara sebagian dosen lain merasa bahwa masih ada mahasiswa yang tidak serius mengikuti perkuliahan online yang berlangsung. Hal ini dikarenakan, dosen sulit untuk mengkondisikan agar mahasiswa siap secara fisik dan psikis untuk mengikuti perkuliahan secara online.

Tanggapan dan pemikiran terhadap perkuliahan online, baik dari mahasiswa maupun dosen, sangat beragam. Pemikiran seseorang terhadap sesuatu dipengaruhi oleh persepsinya terhadap objek tertentu [7]. Reaksi positif akan muncul berdasarkan persepsi positif. Jika individu merasa bahwa rangsangan yang diterimanya bermanfaat dan menyenangkan bagi dirinya, maka individu akan menilai segala yang berkaitan dengan rangsangan itu positif. Demikian sebaliknya, penilaian negatif akan muncul jika individu merasa rangsangan yang diterimanya tidak berguna [8].

Pada proses perkuliahan, persepsi mahasiswa tentang proses pembelajaran dipengaruhi oleh dosen, materi perkuliahan, dan mahasiswa itu sendiri [9]. Pemilihan metode mengajar dan media 
yang akan digunakan dalam proses pembelajaran akan mempengaruhi persepsi mahasiswa terhadap proses perkuliahan tersebut. Selain itu, karakteristik dari setiap mata kuliah juga akan berakibat terhadap pandangan mahasiswa mengenai proses pembelajaran.

Mengetahui pandangan mahasiswa mengenai pembelajaran yang telah berlangsung, sangat penting sebagai pijakan dosen untuk mengambil langkah berikutnya. Hasil penelitian menunjukkan bahwa persepsi siswa mengenai proses pembelajaran yang dilakukan guru dan motivasi untuk berprestasi, akan berpengaruh signifikan terhadap hasil belajar matematika [10]. Persepsi yang baik berkorelasi positif terhadap pencapaian hasil belajar, sementara sikap positif mampu mendorong munculnya motivasi untuk belajar.

Beberapa penelitian telah dilakukan untuk mengetahui persepsi mahasiswa terhadap pembelajaran daring. Seperti penelitian yang dilakukan oleh Kamilah yang mengukur persepsi mahasiswa pendidikan terhadap pembelajaran daring ditinjau dari aspek sarana belajar yang digunakan dosen dalam melaksanakan perkuliahan dan tugas secara online, aplikasi yang efektif bagi mahasiswa dalam melaksanakan perkuliahan dan tugas secara online, terjadinya miskomunikasi saat mengerjakan tugas kelompok, persepsi mahasiswa terhadap lingkungan belajar online, kenyamanan mahasiswa saat menjawab pertanyaan yang diberikan pada saat perkuliahan online, perasaan senang terhadap lingkungan belajar online daripada tatap muka, keinginan agar perkuliahan lebih banyak dilaksanakan secara online daripada tatap muka, lingkungan belajar online memudahkan mahasiswa mengatasi masalah belajar yang dihadapi, perkuliahan online memudahkan mahasiswa memperoleh sumber belajar dan mengakses tugas yang diberikan dosen, serta saran terhadap pelaksanaan perkuliahan daring yang dilakukan dosen [11]. Sejalan dengan ini, penelitian yang dilakukan oleh Anim dan Mapilindo juga mengenai persepsi mahasiswa pendidikan matematika terhadap perkuliahan online. Aspek yang diteliti terkait jenis pembelajaran yang nyaman digunakan mahasiswa pada pembelajaran daring, dan pembelajaran daring membuat proses perkuliahan lebih terorganisir [12]. Penelitian yang penulis lakukan juga terkait persepsi mahasiswa pendidikan matematika terhadap pembelajaran daring. Tetapi aspek yang peneliti teliti memiliki perbedaan dengan penelitian sebelumnya. Aspek yang peneliti teliti yaitu persepsi mahasiswa tentang dirinya selama mengikuti perkuliahan online, persepsi mengenai proses perkuliahan online yang ideal, persepsi terkait perkuliahan online yang terjadi.

Oleh karena itu, penulis tertarik untuk menyelidiki gambaran persepsi mahasiswa Pendidikan Matematika Universitas Riau terhadap perkuliahan online di masa pandemi Covid-19. Tujuan dari penelitian ini untuk menjelaskan persepsi mahasiswa Pendidikan Matematika Universitas Riau terhadap perkuliahan online di masa pandemi Covid-19. Dengan mengetahui persepsi tersebut, dosen dapat mempertimbangkan tindakan selanjutnya yang perlu dilakukan agar kegiatan perkuliahan dapat berlangsung optimal.

\section{METODE}

Penelitian ini bertujuan untuk mengetahui respon mahasiswa Pendidikan Matematika Universitas Riau terhadap perkuliahan online di masa pandemi Covid-19. Rancangan kegiatan dalam penelitian ini yaitu 1) menentukan masalah yang akan dibahas yaitu mengenai gambaran persepsi mahasiswa pendidikan matematika Universitas Riau terhadap perkuliahan 
online di masa pandemi Covid-19; 2) menetapkan lokasi penelitian yaitu di Program Studi Pendidikan Matematika Universitas Riau; 3) menyusun instrumen pengumpulan data yaitu angket persepsi mahasiswa terhadap perkuliahan online; 4) melakukan validasi kepada dua orang ahli terkait angket persepsi; 5) memperbaiki angket persepsi sesuai komentar ahli; 6) melakukan uji validitas dan reliabilitas angket; 7) melakukan perbaikan angket persepsi berdasarkan hasil uji validitas dan reliabilitas; 8) menyebarkan angket persepsi kepada mahasiswa pendidikan matematika Universitas Riau; 9) menganalisis hasil respon angket persepsi; 10) membuat narasi terkait gambaran persepsi mahasiswa pendidikan matematika Universitas Riau terhadap perkuliahan online di masa pandemi Covid-19.

Penelitian ini menggunakan pendekatan kuantitatif deskriptif. Teknik sampling yang digunakan dalam penelitian ini yaitu purposive sampling, yang melibatkan mahasiswa Pendidikan Matematika Universitas Riau angkatan 2017, 2018, dan 2019 sebanyak 121 mahasiswa. Data yang diperoleh dari mahasiswa adalah skor persepsi mahasiswa Pendidikan Matematika FKIP Universitas Riau di masa pandemi Covid-19 terhadap perkuliahan online. Penelitian ini dilaksanakan di Program Studi Pendidikan Matematika FKIP Universitas Riau.

Pengumpulan data persepsi mahasiswa menggunakan angket persepsi. Aspek persepsi yang diukur dalam penelitian ini yaitu: 1) persepsi mahasiswa tentang dirinya selama mengikuti perkuliahan online, 2) persepsi mengenai proses perkuliahan online yang ideal, 3) persepsi terkait perkuliahan online yang terjadi. Sebelum angket persepsi diberikan kepada mahasiswa yang menjadi subjek penelitian, angket tersebut diuji validitas dan reliabilitasnya terlebih dahulu. Setelah angket persepsi dinyatakan valid dan reliabel, angket tersebut kemudian disebarkan kepada mahasiswa yang menjadi subjek penelitian. Data skor persepsi yang diperoleh diolah menggunakan teknik statistik deskriptif. Data skor persepsi yang diperoleh kemudian dikategorikan dengan merujuk pada kategori yang disusun Azwar [13] dan dapat dilihat pada tabel berikut.

\section{Tabel 1. Kategori Persepsi}

\begin{tabular}{cc}
\hline Rentang Skor & Kategori \\
\hline $\mathrm{x}<34$ & Sangat Rendah \\
$34 \leq \mathrm{x}<46$ & Rendah \\
$46 \leq \mathrm{x}<59$ & Sedang \\
$59 \leq \mathrm{x}<71$ & Tinggi \\
$\mathrm{x} \geq 71$ & Sangat Tinggi \\
\hline
\end{tabular}

Sumber: [13]

Data skor mahasiswa yang diperoleh kemudian dikelompokkan berdasarkan kategori tersebut dan dihitung persentasenya untuk masing-masing kategori. Selanjutnya penulis juga menentukan persentase pencapaian masing-masing aspek persepsi yang diukur dan persentase pencapaian persepsi secara keseluruhan. Kategori persentase ketercapaian persepsi yang digunakan merujuk pada Purwanto [14] seperti disajikan pada tabel di bawah ini.

Tabel 2. Kategori Persentase Pencapaian Persepsi

\begin{tabular}{cc}
\hline Persentase & Kategori \\
\hline $86 \leq \mathrm{p} \leq 100$ & Sangat baik \\
$76 \leq \mathrm{p}<86$ & Baik \\
$60 \leq \mathrm{p}<76$ & Cukup \\
$55 \leq \mathrm{p}<60$ & Kurang \\
$\mathrm{p}<55$ & Sangat Kurang \\
\hline & Sumber: [14]
\end{tabular}

Hasil pengolahan data selanjutnya diinterpretasikan. Interpretasi tersebut digunakan untuk memperoleh gambaran persepsi mahasiswa Pendidikan Matematika UNRI terhadap perkuliahan online di masa pandemi Covid-19. 


\section{HASIL DAN PEMBAHASAN}

Data skor persepsi mahasiswa terhadap perkuliahan online yang diperoleh pada penelitian ini diolah agar diperoleh gambaran mengenai persepsi mahasiswa Pendidikan Matematika Universitas Riau terhadap perkuliahan online selama masa pandemi Covid-19. Skor persepsi masingmasing mahasiswa dikelompokkan ke dalam kategori persepsi. Hasil pengelompokan tersebut, dapat dilihat pada tabel berikut.

\section{Tabel 3. Hasil Pengelompokan Persepsi} Mahasiswa

\begin{tabular}{ccc}
\hline Kategori & Jumlah & Persentase (\%) \\
\hline Sangat rendah & 0 & 0 \\
Rendah & 0 & 0 \\
Sedang & 77 & 63,64 \\
Tinggi & 43 & 35,54 \\
Sangat tinggi & 1 & 0,83 \\
\hline
\end{tabular}

Berdasarkan tabel 3 tersebut, terlihat bahwa persepsi mahasiswa berada pada kategori sedang, tinggi, dan sangat tinggi. Kategori sedang merupakan kategori dengan jumlah mahasiswa terbanyak yaitu 77 orang dengan persentase sebesar $63,64 \%$. Kategori tinggi dengan jumlah 43 orang mahasiswa dan persentase sebesar $35,54 \%$. Selanjutnya, jumlah mahasiswa yang termasuk dalam kategori sangat tinggi ada 1 orang dengan persentase $0,83 \%$. Dari data ini, berarti mahasiswa pendidikan matematika UNRI sudah memiliki persepsi yang cukup baik terhadap pelaksanaan perkuliahan online selama masa pandemi Covid-19.

Selanjutnya peneliti menentukan persentase skor persepsi terhadap pelaksanaan perkuliahan online untuk masing - masing indikator dan membandingkannya dengan kategori yang telah ditentukan sebelumnya. Hasil penentuan persentase skor persepsi dapat dilihat pada tabel berikut.
Tabel 4. Hasil Perhitungan Persentase

Pencapaian Persepsi terhadap

Perkuliahan Online untuk MasingMasing Indikator

\begin{tabular}{|c|c|c|c|}
\hline Aspek & Indikator & $\begin{array}{c}\text { Persentase } \\
\text { Skor } \\
\text { Persepsi } \\
(\%)\end{array}$ & Kategori \\
\hline \multirow[t]{2}{*}{$\begin{array}{l}\text { Persepsi } \\
\text { mahasiswa } \\
\text { tentang } \\
\text { dirinya } \\
\text { selama } \\
\text { mengikuti } \\
\text { perkuliahan } \\
\text { online }\end{array}$} & $\begin{array}{l}\text { Menumbuhk } \\
\text { an sikap aktif } \\
\text { dalam proses } \\
\text { pembelajaran } \\
\text { Menumbuhk } \\
\text { an motivasi } \\
\text { dalam proses } \\
\text { pembelajaran }\end{array}$ & 71,07 & Kurang \\
\hline & $\begin{array}{l}\text { Menumbuhk } \\
\text { an sikap } \\
\text { belajar } \\
\text { mandiri } \\
\text { Meningkatka } \\
\text { n } \\
\text { pemahaman }\end{array}$ & 65,19 & Cukup \\
\hline $\begin{array}{l}\text { Persepsi } \\
\text { mengenai } \\
\text { proses } \\
\text { perkuliahan } \\
\text { online yang } \\
\text { ideal }\end{array}$ & $\begin{array}{l}\text { Penyajian } \\
\text { materi kuliah } \\
\text { Pengelolaan } \\
\text { kelas } \\
\text { Penilaian } \\
\text { Akses }\end{array}$ & $\begin{array}{l}89,36 \\
75,1 \\
72,42 \\
79,24 \\
\end{array}$ & $\begin{array}{l}\text { Sangat } \\
\text { Baik } \\
\text { Cukup }\end{array}$ \\
\hline $\begin{array}{l}\text { Persepsi } \\
\text { terkait } \\
\text { perkuliahan } \\
\text { online yang } \\
\text { terjadi }\end{array}$ & $\begin{array}{l}\text { Penyajian } \\
\text { materi kuliah } \\
\text { Pengelolaan } \\
\text { kelas } \\
\text { Penilaian } \\
\text { Akses }\end{array}$ & $\begin{array}{c}39,77 \\
76,55 \\
62,29 \\
50\end{array}$ & $\begin{array}{l}\text { Sangat } \\
\text { Kurang } \\
\text { Cukup }\end{array}$ \\
\hline
\end{tabular}

Berdasarkan tabel tersebut, terlihat persentase skor dan kategori di masingmasing indikator. Jika dikelompokkan berdasarkan kategorinya, maka ada 2 indikator yang berada pada kategori sangat kurang, 1 indikator berada pada kategori kurang, 7 indikator berada pada kategori cukup, 1 indikator berada pada kategori baik, dan 1 indikator berada pada kategori sangat baik.

Indikator persepsi terhadap perkuliahan online yang berada pada kategori sangat kurang yaitu indikator "Penyajian materi kuliah" dan "Akses" pada aspek "Persepsi terkait perkuliahan online yang terjadi". 
Berarti persepsi terkait perkuliahan yang terjadi belum sesuai dengan persepsi perkuliahan online yang diharapkan mahasiswa. Penyajian materi kuliah selama pandemi Covid-19 belum mampu menarik minat mahasiswa dan memberikan pemahaman kepada mahasiswa terhadap materi perkuliahan. Padahal menurut Fortune, Spielman, dan Pangelinan, materi belajar merupakan salah satu permasalahan yang perlu mendapat perhatian dalam melaksanakan perkuliahan online [15]. Materi belajar tersebut hendaknya sesuai dengan kebutuhan mahasiswa dan mudah untuk dipahami. Selain itu akses internet yang kurang stabil juga menjadi kendala yang dirasakan mahasiswa dalam mengikuti perkuliahan secara online. Permasalahan ini sesuai dengan hasil penelitian Haqien dan Rahman, yaitu salah satu hal yang membuat penggunaan Zoom Meeting tidak efektif pada saat perkuliahan online adalah sinyal internet yang kurang stabil dikarenakan mahasiswa tersebut tidak menggunakan jaringan wifi [16].

Indikator yang berada pada kategori kurang yaitu indikator "Menumbuhkan motivasi dalam proses pembelajaran" pada aspek "Persepsi mahasiswa tentang dirinya selama mengikuti perkuliahan online" dengan persentase skor sebesar 59,3\%. Berarti mahasiswa masih kurang termotivasi selama mengikuti perkuliahan online di masa pandemi Covid-19. Hasil penelitian ini sejalan dengan hasil yang diperoleh pada penelitian Meşe dan Sevilen, yaitu siswa secara umum merasa bahwa pembelajaran online berdampak negatif pada motivasi mereka dikarenakan kurangnya interaksi sosial, ketidaksesuaian antara harapan dan konten, dan lingkungan belajar [17].

Indikator yang berada pada kategori cukup yaitu indikator "menumbuhkan sikap aktif dalam proses pembelajaran", "menumbuhkan sikap belajar mandiri", dan "meningkatkan pemahaman" pada "aspek persepsi mahasiswa tentang dirinya selama mengikuti perkuliahan online". Artinya perkuliahan online yang diikuti sudah cukup mampu untuk membuat mahasiswa aktif dalam proses belajar, mandiri dalam belajar, serta meningkatkan pemahaman mahasiswa. Hal ini sejalan dengan penelitian yang dilakukan oleh Siregar dan Siregar, bahwa mahasiswa sudah bisa beradaptasi dalam mengikuti perkuliahan online di masa pandemi Covid-19 dan memiliki kemandirian belajar yang baik, ditandai dengan pencapaian self regulation mahasiswa berada pada kategori sedang, tinggi, dan sangat tinggi [18].

Indikator pengelolaan kelas dan penilaian pada aspek persepsi mengenai proses perkuliahan online yang ideal dan indikator pengelolaan kelas dan penilaian pada aspek persepsi terkait perkuliahan online yang terjadi, berada pada kategori cukup. Artinya pada indikator pengelolaan kelas dan penilaian, persepsi mahasiswa mengenai perkuliahan online yang ideal dengan persepsi mahasiswa mengenai perkuliahan online yang terjadi, tidak berbeda secara signifikan. Namun, pengelolaan kelas pada perkuliahan online perlu ditingkatkan, agar aktivitas mahasiswa pada perkuliahan tetap terkontrol dan tidak muncul kejenuhan dalam diri mahasiswa, seperti dengan menggunakan model pembelajaran yang bervariasi [19].

Secara keseluruhan, pelaksanaan perkuliahan online pada Program Studi Pendidikan Matematika Universitas Riau telah memperoleh respon positif dari mahasiswa. Hasil penelitian ini sejalan dengan hasil penelitian yang diperoleh Erin dan Maharani, yaitu $85 \%$ respnden mahasiswa memiliki persepsi yang positif terhadap pembelajaran daring. Menurut mahasiswa tersebut, jika jaringan internet 
baik, maka perkuliahan online nyaman dan efektif untuk dilakukan [20]. Penelitian yang dilakukan oleh Rimo juga memperoleh hasil yang serupa. Pada penelitian tersebut, $66,15 \%$ mahasiswa memberikan respon yang sangat positif terhadap perkuliahan daring dengan youtube pada mata kuliah aljabar linear [21].

Dilihat persentase persepsi per indikator, masih ada indikator yang berada pada kategori kurang dan cukup. Artinya, proses pembelajaran memerlukan perbaikan. Cara yang dapat dilakukan untuk mengoptimalkan perkuliahan online antara lain: 1) melibatkan mahasiswa secara aktif dalam kegiatan pembelajaran; 2) mendorong mahasiswa untuk berinteraksi dan mendiskusikan materi perkuliahan dengan mahasiswa lain dalam rangka menciptakan lingkungan yang mendukung kegiatan perkuliahan; 3) menggunakan model pembelajaran yang berbeda dalam setiap pertemuan; 4) melaksanakan penilaian atau refleksi di akhir pembelajaran menggunakan berbagai situs atau aplikasi secara online; 5) menyajikan materi kuliah yang dapat diakses baik secara sinkronus maupun asinkronus.

\section{SIMPULAN}

Secara keseluruhan, pelaksanaan perkuliahan online pada Program Studi Pendidikan Matematika Universitas Riau telah memperoleh respon positif, yaitu berada pada kategori sedang, tinggi, dan sangat tinggi. Dilihat dari indikator yang digunakan pada setiap aspek yang diteliti, maka: 1) pada aspek persepsi mahasiswa tentang dirinya selama mengikuti perkuliahan online, 3 indikator berada pada kategori cukup dan 1 indikator berada pada indikator kurang; 2) pada aspek persepsi mengenai proses perkuliahan online yang ideal, 1 indikator berada pada kategori sangat baik, 1 indikator berada pada kategori baik, dan 2 indikator berada pada kategori cukup; 3) pada aspek persepsi terkait perkuliahan online yang terjadi, 2 indikator berada pada kategori cukup dan 2 indikator berada pada kategori sangat kurang. Cara yang dapat dilakukan untuk mengoptimalkan perkuliahan online yaitu melibatkan mahasiswa secara aktif dalam kegiatan pembelajaran, mendorong interaksi antar mahasiswa, menggunakan model pembelajaran yang berbeda di setiap pertemuan, melaksanakan penilaian atau refleksi di akhir pembelajaran secara online, menyajikan materi kuliah yang dapat diakses baik secara sinkronus maupun asinkronus.

\section{DAFTAR PUSTAKA}

[1] Y. C. Wu, C. S. Chen, and Y. J. Chan, "The outbreak of COVID-19: An overview," J. Chinese Med. Assoc., vol. 83, no. 3, pp. 217-220, 2020.

[2] A. Joharudin, M. A. Septiadi, S. Maharani, T. D. Aisi, and Nurwahyuningsih, "Panic Syndrom Covid-19: Penekanan Terhadap Kebijakan Yang Diberikan," $J$. Perspekt., vol. 4, no. 1, pp. 44-53, 2020.

[3] A. K. Pakpahan, "Covid-19 Dan Implikasi Bagi Usaha Mikro, Kecil, Dan Menengah," J. Ilm. Hub. Int., vol. Edisi Khus, pp. 59-64, 2020.

[4] S. Azis, "Cerita Mahasiswa Kuliah Daring, Cegah Penularan Wabah Covid-19," Telisik.id, 2020. [Online]. Available:

https://telisik.id/news/ceritamahasiswa-kuliah-daring-cegahpenularan-wabah-covid-19. [Accessed: 17-Nov-2020].

[5] D. Sutrisno, "Curhat Mahasiswa Kuliah Online, Banyaknya Tugas Hingga Rindu Ngampus," IDN Times, 2020. [Online]. Available: https://jabar.idntimes.com/news/jabar /debbie-sutrisno/curhat-mahasiswakuliah-online-banyaknya-tugas- 
hingga-rindu-ngampus/6. [Accessed: 05-Jul-2020].

[6] N. Sucahyo, "Kuliah Daring Karena Corona, Mahasiswa Keluhkan Paket Data," VOA Indonesia, 2020. [Online]. Available: https://www.voaindonesia.com/a/kuli ah-daring-karena-corona-mahasiswakeluhkan-paket-data-/5333590.html.

[7] Desmita, Psikologi Perkembangan Peserta Didik. Bandung: PT Remaja Rosdakarya, 2012.

[8] W. S. Winkel, Psikologi Pengajaran. Yogyakarta: Media Abadi, 2019.

[9] N. Kurniati, B. Baidowi, and N. Hikmah, "Persepsi Mahasiswa Pendidikan Matematika Terhadap Kinerja Dosen dalam Proses Perkuliahan," J. PIJAR MIPA, vol. 13, no. 1, pp. 32-36, 2018.

[10] L. Sahidin and D. Jamil, "Pengaruh Motivasi Berprestasi dan Persepsi Siswa Tentang Cara Guru Mengajar Terhadap Hasil Belajar Matematika," J. Pendidik. Mat., vol. 4, no. 2, pp. 212-222, 2013.

[11] A. N. Kamilah, N. Hidayati, and Haerudin, "Persepsi Mahasiswa Pendidikan Matematika Terhadap Pembelajaran Daring Semasa Pandemi Covid-19," Pythagoras J. Progr. Stud. Pendidik. Mat., vol. 10, no. 1, pp. 66-75, 2021.

[12] Anim and Mapilindo, "Persepsi Mahasiswa Pendidikan Matematika Tentang Pembelajaran Daring Selama Masa Learn From Home (LFH) Pandemi Covid-19," J. Mat. Paedagog., vol. 5, no. 1, pp. 72-80, 2020.

[13] S. Azwar, Penyusunan Skala Psikologi. Yogyakarta: Pustaka Pelajar, 2012.

[14] Purwanto, Metodologi Penelitian Kuantitatif untuk Psikologi dan Pendidikan. Yogyakarta: Pustaka Pelajar, 2012.

[15] M. F. Fortune, M. Spielman, and D.
T. Pangelinan, 'Students' Perceptions of Online or Face-toFace Learning and Social Media in Hospitality, Recreation and Tourism," MERLOT J. Online Learn. Teach., vol. 7, no. 1, pp. 1-16, 2011.

[16] D. Haqien and A. A. Rahman, "Pemanfaatan Zoom Meeting untuk Proses Pembelajaran pada Masa Pandemi Covid-19," SAP (Susunan Artik. Pendidikan), vol. 5, no. 1, pp. 51-56, 2020.

[17] E. Meşe, Ç. Sevilen, and A. Info, "Factors Influencing EFL Students' Motivation in Online Learning: A Qualitative Case Study," J. Educ. Technol. Online Learn., vol. 4, no. 1, pp. 11-22, 2021.

[18] H. M. Siregar and S. N. Siregar, "Profil Self Regulation Mahasiswa Pendidikan Matematika FKIP Universitas Riau di Masa Pandemi Covid-19," ANARGYA J. Ilm. Pendidik. Mat., vol. 4, no. 1, pp. 110, 2021.

[19] E. S. Rosali, “Aktifitas Pembelajaran Daring Pada Masa Pandemi Covid19 di Jurusan Pendidikan Geografi Universitas Siliwangi Tasikmalaya," Geogr. Sci. Educ. J., vol. 1, no. 1, pp. 21-30, 2020.

[20] Erin and A. Maharani, "Persepsi Mahasiswa Pendidikan Matematika terhadap Perkuliahan Online," Mosharafa J. Pendidik. Mat., vol. 7, no. 3, pp. 337-344, 2018.

[21] I. H. E. Rimo, "Persepsi Mahasiswa Pendidikan Matematika FKIP Undana Tentang Perkuliahan Daring Berbantuan Youtube Pada Mata Kuliah Aljabar Linear," FRAKTAL J. Mat. DAN Pendidik. Mat., vol. 2, no. 1, pp. 14-22, 2021. 